\title{
UNITED NATIONS PEACEKEEPING OPERATIONS IN THE ERA OF COVID-19
}

\author{
Amanda M. Makosso, Simon Fraser University
}

\begin{abstract}
With its seven peacekeeping operations deployed in the African continent, the United Nations peacekeeping seeks to maintain peace and security by helping African states create conditions for sustainable peace. As COVID-19 has exposed the international system's vulnerability, this analysis seeks to explore what Peacekeeping looks like in the COVID-19 era. By drawing on news articles, reports, and United Nations press releases, this account also examines the challenges faced by peacekeepers in Sub Saharan Africa, a region well known for violent conflicts and warfare. It is interesting to note that peacekeeping in the COVID 19 era appears to have struck a balance between protecting people's health, ensuring civilians protection from threats of physical violence, and taking gender dynamics into account. However, operational changes in peacekeeping missions resulting from COVID19 seem to have a serious effect on missions and troops and might raise severe implications for the future of peacekeeping in Africa.
\end{abstract}

"It may seem as if the world is falling apart, as crises pile up and disease spreads. But leadership is precisely about finding the seeds of hope and nurturing them into something bigger."

-Former UN Secretary-General Ban Ki-moon

The United Nations peacekeeping seeks to maintain international peace and security by helping countries experiencing conflict create sustainable peace (United Nations Peacekeeping, para.1). Over the past decade, peacekeeping operations have been criticized for a variety of reasons, including the failure to prevent attacks in some countries, the use of force, or even the allegations of sexual abuse perpetrated by some peacekeepers on the very same people they were meant to protect (Donald, 2003; Boutellis, 2013; Human Rights Watch, 2014; Lee \& Bartels, 2019). However, it is a widely held view that peacekeepers have contributed to "reducing the frequency and lethality of war" in societies (Bellamy, 2010, p. 153). It is thought that peacekeeping missions have promoted peace and security by shortening episodes of conflicts in conflict-prone locations or reducing civilians' killings in wars, for instance (Hultman et al., 2013; Ruggeri et al., 2016). However, peacekeeping is currently facing a wide array of 
challenges in the COVID-19 era, specifically in Africa. Countries such as Mali, the Democratic Republic of the Congo, or Niger are still experiencing armed violence and conflicts despite the appeal of the United Nations SecretaryGeneral for a Global Ceasefire in March 2020 (Norwegian Refugee Council, 2020).

A full discussion of the effectiveness of peacekeeping operations in the era of COVID 19 is beyond the scope of this analysis; this account sought nonetheless to explore what peacekeeping looks like in the COVID-19 era. It is interesting to note that although it remains essential for peacekeepers to reduce security threats posed by armed groups, peacekeeping operations are also supporting national authorities' response to COVID-19. Most importantly, peacekeeping operations in 2020 are not limited to protecting vulnerable communities only but are also considering COVID-19 mitigation measures and the safety, security, and health of peacekeeping personnel. Such considerations seem essential to fulfill the civilian protection mandate, maintain public support for peacekeeping, and implement a more adaptive approach to peace operations.

\section{Protecting civilians in the COVID-19 era}

\section{Understanding the role of UN peacekeeping}

UN peacekeeping missions have an explicit mandate to protect civilians by preventing or responding to threats of physical violence against local populations in the Democratic Republic of the Congo (DRC), the Central African Republic (CAR), Mali, South Sudan, Darfur, and Abyei (United Nations Peacekeeping, para 1). Most importantly, the United Nations tend to foster a people centered approach to peacekeeping. Peacekeepers work closely with local communities "to document human rights violations, assess protection needs and threats, design local protection plans and early warning mechanisms, and strengthen dialogue and mediation to defuse tensions." (Di Razza, 2020, para. 10). Communication between peacekeepers and local populations is, therefore, at the center of the civilian protection mandate. UN peacekeeping missions have indeed incorporated a holistic approach to civilian protection by not only ensuring the physical protection of local communities from any threat of violence but also by pursuing dialogue and engagement with communities (Di Razza, 2020, para. 10).

In their thorough examination on the effectiveness of peacekeepers in protecting civilians from violence, Fjelde et al. (2019) were able to show that "the more peacekeeping forces deployed to a location, the less likely that rebel groups will carry out attacks in these areas" (p. 4). In the same vein, Fortna notes that 
"peacekeeping has a significant impact on the stability of peace" (p. 9). As the table below shows, six U.N. peacekeeping missions are currently active in SubSaharan Africa.

\section{Table 1}

UN peacekeeping Missions in Africa

\begin{tabular}{|c|c|}
\hline Peacekeeping Missions & Mandates \\
\hline $\begin{array}{l}\text { The U.N. Multidimensional } \\
\text { Integrated Stabilization Mission in } \\
\text { the Central African Republic } \\
\text { (MINUSCA) }\end{array}$ & $\begin{array}{l}\text { - Protection of civilians } \\
\text { - Support for the extension of state } \\
\text { authority } \\
\text { - Assistance in the peace process } \\
\text { - Protection of humanitarian aid } \\
\text { delivery }\end{array}$ \\
\hline $\begin{array}{l}\text { The U.N. Multidimensional } \\
\text { Integrated Stabilization Mission in } \\
\text { Mali (MINUSMA) }\end{array}$ & 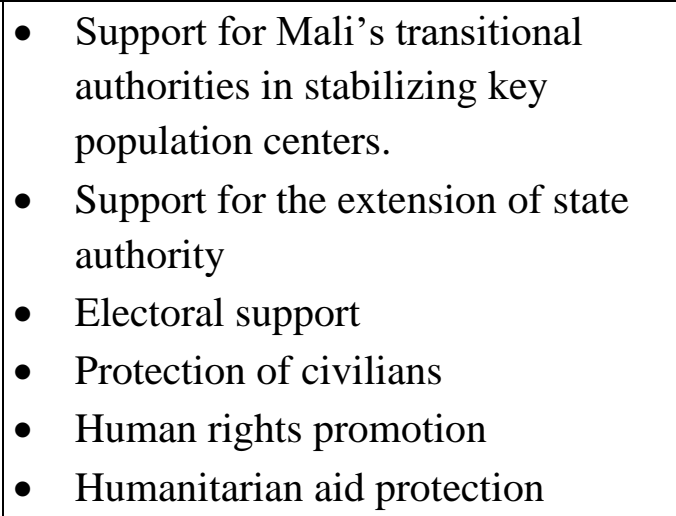 \\
\hline $\begin{array}{l}\text { The U.N. Interim Security Force for } \\
\text { Abyei (UNISFA) }\end{array}$ & $\begin{array}{l}\text { - Support for broader border security } \\
\text { arrangements between South Sudan } \\
\text { and North Sudan }\end{array}$ \\
\hline $\begin{array}{l}\text { The U.N. Mission in South Sudan } \\
\text { (UNMISS) }\end{array}$ & $\begin{array}{ll}\text { - } & \text { Protection of civilians } \\
\text { - } & \text { Human rights abuses investigation } \\
\text { - } & \text { Support for Ceasefire monitoring }\end{array}$ \\
\hline $\begin{array}{l}\text { The U.N. Organization Stabilization } \\
\text { Mission in the Democratic Republic } \\
\text { of the Congo (MONUSCO) }\end{array}$ & $\begin{array}{l}\text { - Protection of civilians } \\
\text { - Support for the extension of state } \\
\text { authority in eastern DRC } \\
\text { - Protection of U.N. personnel and } \\
\text { facilities }\end{array}$ \\
\hline
\end{tabular}




\begin{tabular}{|l|l|}
\hline & $\begin{array}{l}\text { Support for the demobilization of } \\
\text { rebel combatants and support for } \\
\text { institutional and security sector } \\
\text { reforms }\end{array}$ \\
\hline $\begin{array}{l}\text { The African Union-United Nations } \\
\text { Mission in Darfur (UNAMID) }\end{array}$ & $\bullet \begin{array}{l}\text { Protection of U.N. personnel, aid } \\
\text { workers, and civilians }\end{array}$ \\
& $\begin{array}{l}\text { Support role in implementing a } \\
2006 \text { peace deal } \\
\text { Monitoring and conflict mitigation } \\
\text { responsibilities }\end{array}$ \\
\hline
\end{tabular}

(Congressional Research Service, p. 11, 2019)

Note: Peacekeeping missions tasks mentioned above are non-exhaustive.

\section{Restrictions and implications}

Recent evidence suggests that "fewer civilians died in areas protected by U.N. peacekeeping troops" since "the presence of combat-ready peacekeepers helped protect civilian lives" (Prins \& Phaya, 2018, para. 10). However, mitigation measures, restrictions, the suspension of new deployments, and the unintended economic and political consequences of COVID-19 might affect civilians' protection. From the very start of the coronavirus crisis, mitigation and restrictive measures seem to have affected peacekeepers' ability to fulfill the civilian protection mandate. Travel restrictions had delayed police units' deployment in the contested territory of Abyei, the border between South and North Sudan (United Nations, 2020). COVID-19 had also limited the ability of the UN interim force in Abyei's (UNISFA) to pursue its "weapons-free-zone" mandate (Di Razza, 2020).

Preventive measures have included movement restrictions, temporary closure of international borders, and suspension of flights (Bizimana, 2020). Consequently, peace support operations' rotations were suspended, including in conflict zones such as DRC or Mali, until June 30th (Bizimana, 2020). Precautionary measures have included the suspension of peacekeeping rotation from six Asian countries, namely China, South Korea, India, Nepal, and Cambodia. Peacekeeping rotations involve the deployment of peacekeepers in mission areas "for a period between six months and one year before being replaced" (Bizimana, 2020). 
While peacekeepers' routines are changing, violence conflicts run its course in some parts of Africa, including violent extremism with attacks from Boko Haram, Al Shabaab, the Islamist states in Boma, Somalia, and Mozambique (Desmidt \& Neat, 2020, p. 2). In DRC, the Allied Democratic Forces (ADF) are presumed to have launched an attack on a MONUSCO convoy (United Nations, 2020). Consequently, a major problem with the suspension of peacekeeping rotations is the impact of more prolonged deployment on peacekeepers' mental health (stress, fatigue), which might affect the overall performance of peacekeeping operations in these stressful environments (Nagel \& Verveer, 2020).

One of the most serious effects of the COVID-19 outbreak remains the unintended political consequences of the pandemic. That is the global recession that might affect the economy of main peacekeeping contributors. Conflict and tensions exacerbated by the global epidemic imply that the demand for largescale U.N peacekeeping missions might be higher in conflict zones. However, the effect of COVID 19 on the global economy might lead the United Nations "to prioritize smaller scale mechanisms that rely on small military teams and civilian specialists as affordable alternatives to large and costly deployments" (Anderson and Gowan, 2020). This may, in turn, lead armed groups to take advantage of the reduced presence of peacekeepers to commit acts of violence against the civilian populations.

Ensuring civilians' protection while supporting COVID-19 mitigation UN peacekeeping missions have still maintained the activities entrenched in the Civilian Protection Mandate. Some examples include:

- Electoral assistance by supporting political processes in Mali. MINUSMA has supported the smooth execution of the legislative elections in April 2020, which led to women's accession to political decision-making with $28,57 \%$ of women elected in the national assembly (United Nations peacekeeping, 2020; DGC, 2020, MINUSMA, 2020).

- Protection and promotion of human rights by helping free 38 civilians, including women and children in DRC, as reported by Abdul Khare and Jean Pierre Lacroix, respectively, the Under-Secretary-General of the UN Department of Operational Support and the Under-Secretary-General of the UN Department of Peace Operations. (Khare \& Lacroix, 2020).

- And deployment to prevent the outbreak of conflict by redeploying the UN Mission in DRC forces in the politically unstable province of North Kivu (MONUSCO, 2020). 
Although it remains essential for peacekeepers to reduce security threats posed by armed groups, peacekeeping operations are also supporting national authorities' response to COVID-19 and containing and mitigating the spread of COVID-19. As highlighted by the United Nations, MONUSCO, for instance, has taken a comprehensive approach that includes "troop deployments in hotspot areas to protect civilians and large-scale logistical support to Government armed forces" (United Nations, 2020). Besides, MONUSCO is also supporting host governments to limit the spread of the COVID-19 virus by providing masks and hand sanitizers to local populations in North Kivu (MONUSCO, 2020).

Peacekeeping missions in 2020 are not limited to protecting vulnerable communities only but are also considering the safety, security, and health of peacekeeping personnel. As a result, peacekeepers had introduced new practices in the light of the pandemic, including teleworking, video-conferencing, and social distancing during community engagement (De Coning, 2020). The case of Sudan illustrates perfectly this adaptability. In May 2020, peace negotiations between the Sudanese government and the Sudan Revolutionary Front (SRF) occurred online via video conference and resulted in agreements on the holding of elections (Desmidt \& Neat, 2020, p.4).

\section{Protecting vulnerable groups}

In the context of COVID-19, protecting civilians also means focusing on the gender dimension of the pandemic. Women and girls are profoundly affected by crisis and conflict, heightening pre-existing inequalities (UN Women, 2020, p. 2). With its mandate to implement the Security Council Resolutions on Women, Peace, and Security, (WPS), peacekeeping operations are required to focus "on a gendered approach to multidimensional peacekeeping missions" (PeaceWomen, 2020). Resolution 1325 reaffirms the critical role of women in the prevention, management, resolution of conflict, peacebuilding efforts, and peacekeeping operations (United Nations, 2020). Most importantly, it stresses the importance of women's equal participation and involvement in all efforts for the maintenance and promotion of peace and security and seeks to protect women and girls from gender-based violence, including sexual violence in conflict and post-crisis situations (United Nations, 2020). Peace operations are, therefore, becoming more gender responsive in their missions. As reported by the United Nations, "the percentage of MINUSCO mission work plans, including at least one gender-specific goal has increased from $69 \%$ in 2017 to $91 \%$ in 2019 " (Martin, 2020). 
However, COVID-19 has exacerbated social inequalities faced by women and girls in conflict areas (Perianes, 2020). This includes barriers in access to health services due to gender discrimination and inequality, a rise in gender-based violence, and an increase in violence against women (Perianes, 2020). Furthermore, marginalized groups such as women and children in conflict zone "are more likely to find themselves at increased risk of violence, abuse, child marriage and recruitment to armed groups" (Sadeque, 2020). As a result, women peacekeepers appear to be on the frontline of the COVID-19 response in countries such as South Sudan, DRC, or Darfur (UN Peacekeeping, 2020). Therefore, protecting women and girls for peacekeepers entail taking special measures to mitigate the harmful effects of the pandemic on women and girls by "organizing awareness campaigns on COVID 19 (transmission, prevention, safety measures)" or providing "materials and dignity kits as well as handwashing supplies to internally displaced women and girls" (Martin, 2020).

As for women's political participation, despite the low voter turnout in the legislative elections in Mali, 28.57\% women were elected in the National Assembly (MINUSMA, 2020). This is still an improvement as only $9.52 \%$ of women were elected in the national assembly in 2013 (Mali National Assembly, 2016). Consequently, this election correctly illustrates some progress on women's political empowerment.

\section{Building confidence and trust in the COVID-19 era}

Local support remains the cornerstone of effective peace operations. As the Lessons Learned Unit Department of Peacekeeping Operations highlights:

The support of the local population is essential to the success of a peacekeeping operation as the lack of local support not only hinders the operations in the implementation of its mandate and the conduct of daily activities but can also pose a physical danger to the mission's personnel. (United Nations, 1996, p. 39)

Consequently, the United Nations' (UN) Department of Peacekeeping Operations (DPKO) emphasizes that the three essential factors of successful peace operations are legitimacy, credibility and local ownership:

The experiences of the past 15 years have shown that in order to succeed, United Nations peacekeeping operations must also be perceived as legitimate and credible, particularly in the eyes of the local population ... The manner in which a United Nations peacekeeping operation conducts 
itself may have a profound impact on its perceived legitimacy on the ground (UN DPKO, 2008, p. 36).

As a result, confidence-building and cooperation is crucial between local communities and peacekeepers. However, confidence-building and collaboration during a pandemic are challenging since local communities appear to be concerned by the risks of spreading infectious diseases posed by peacekeepers. These suspicions could lead to hostility against peacekeepers. Drawing on extensive research on African peacekeeping, Cedric de Coning underlines how the COVID-19 pandemic has disrupted peace operations on the African continent and points out that: "in some countries" such as Central African Republic, DRC or Mali "there are fears, rumours, and (...) active disinformation campaigns, that foreign peacekeepers are responsible for spreading the virus" (De Coning, 2020, p. 2). As a result, the global pandemic raises challenging questions for peacekeepers, including "whether troops should wear masks to reassure the population, or whether wearing masks in situations where that is not the norm among the population will only increase such fears and rumours" (De Coning, 2020).

It is true that prior to the COVID-19 outbreak, there was already an apparent lack of trust in MINUSCA due to allegations of sexual abuses by some peacekeepers and perceived failure to conflict resolution in the region (Losh, 2020). However, local communities appear to harbor a deep mistrust of peacekeepers amidst COVID-19. Findings of the recent research of the Political Settlements Research Programme (PSRP) (2020) on the impact of Covid-19 on Peace and Transition Processes reveal that:

Respondents reported references to Covid-19 as the 'MINUSCA virus,' and other instances of anti-UN sentiments (...) one respondent noted that 'UN staff in the CAR are seen as being responsible for bringing the virus to the country while another respondent referred to the '[s]tigmatisation of international staff of UN and NGOs as bringing the disease into the country' in South Sudan" (p. 13).

Consequently, building local support, confidence, and trust in the COVID-19 era means ensuring that peacekeepers are not a contagion vector and implementing community outreach that considers this new "normal" (United Nations, 2020). The global pandemic has led the United Nations Peacekeeping to adapt its daily operations by including mitigation measures against the spread of the COVID 19 to help protect peacekeepers and local communities: 
- Ensuring local communities have access to accurate information about COVID 19 through various communications channels such as radio and social media. (United Nations, 2020)

- Informing the local population about COVID-19 in local languages, educating on mitigation measures, and addressing rumours and countering misinformation. (Department of Peace Operations Strategic Communications 2020, p. 1)

COVID-19 has taught humanity several lessons. The first is that a multidimensional perspective to security is critical to ensure peace. While peace operations have focused on addressing conflicts (despite the current circumstances), COVID-19 mitigations measures or the emphasis on the gender dimension of COVID-19 tend to be essential factors to protect civilians in conflict zones. Peacekeeping operations will still be needed more than ever in the future as the economic and social effects of COVID-19 might likely cause greater political and economic instability in conflict-prone societies. COVID 19 can potentially exacerbate discrimination based-grievances, mistrust and feelings of injustice due to limited access to health services, unemployment, food insecurity (International Labour Conflict, 2020). These factors are potential drivers of conflict (International Labour Conflict, 2020; United Nations Interagency Framework Team for Preventive Action, 2012; Ogharanduku, 2017).

Furthermore, the recent coup d'état in Mali in August 2020 might again pose a challenge for peacekeeping in maintaining stability and restoring security (FRANCE 24, 2020). Therefore, maintaining peace might be difficult to achieve but not impossible. Consequently, key factors to promote, foster, and encourage peace within African nations postCOVID-19 should include:

- Fostering local support for peace operations.

- Involving more uninformed and civil actors' women in peace processes.

- And ensuring that peacekeeping operations encompass a holistic approach to civilians' protection by going beyond military intervention to address the root causes of violent conflicts. 


\section{References}

Bell, C., Epple, T., \& Pospisil, J. (2020). The Impact of COVID-19 on Peace and Transition Processes: Tracking the Trends (PSRP Research Report: Covid-19 Series). Edinburgh: Global Justice Academy, University of Edinburgh. Retrieved from https://www.politicalsettlements.org/wpcontent/uploads/2020/06/NexusReport-Digital.pdf

Bellamy, Alex J. (2010). Peace operations and humanitarian intervention. In Issues in Beeson M. \& Bisley N. (Eds) 21st Century World Politics, pp. 149-161. Basingstoke; New York: Palgrave Macmillan.

Bizimana C. (2020, August 05). Impact of COVID-19 on peace support operations in Africa. The African Centre for the Constructive Resolution of Disputes. Retrieved from https://www.accord.org.za/analysis/impactof-covid-19-onpeace-support-operations-in-africa/

Blanchfield, L., Arieff, A., \& Blanchard, L. P. (2019). U.N. peacekeeping operations in Africa. Congressional Research Service. Retrieved from https://fas.org/sgp/crs/row/R45930.pdf

Boutellis, J. (2013). From Crisis to Reform: Peacekeeping Strategies for the Protection of Civilians in the Democratic Republic of the Congo Stability. International Journal of Security \& Development, 2(3): 48, pp. 1-11. http://dx.doi.org/10.5334/sta.ci

De Coning C. (2020, May 13). Examining the Longer-Term Effects of COVID19 on UN Peacekeeping Operations. International Peace Institute. Retrieved from https://theglobalobservatory.org/2020/05/examininglonger-term-effectscovid-19-un-peacekeeping-operations/

Desmidt, S. \& Neat A. (2020). COVID-19 in Africa: Driver of conflict, or too early to tell? The European Centre for Development Policy Management. Retrieved from https://ecdpm.org/wpcontent/uploads/COVID-19-Africa-Driver-Conflict-Too-Early-TellECDPM-Briefing-Note-118-June-2020-1.pdf

Di Razza N. (2020, May 22). UN Peacekeeping and the Protection of Civilians in the COVID-19 Era. International Peace Institute. Retrieved from 
https://theglobalobservatory.org/2020/05/un-peacekeeping-protectionofcivilians-in-covid-19-era/

Donald, D. (2003). Neutral is Not Impartial: The Confusing Legacy of Traditional Peace Operations Thinking. Armed Forces and Society, 29, pp. 415-448. https://doi.org/10.1177/0095327X0302900306

DPO Strategic Communications. (2020, May 22). COVID 19 UN

Peacekeeping. Retrieved from https://peacekeeping.un.org/sites/default/files/20200522_peacekeeping_ comm unity_outreach_and_covid.pdf

Fjelde, H., Hutman, L., \& Nilsson, D. (2019). Protection Through Presence: UN Peacekeeping and the Costs of Targeting Civilians. International Organization. 73 (1). pp. 103-131. https://doi.org/10.1017/S0020818318000346

Fortna, V. P. (2007). Does peacekeeping work? Shaping belligerents' choices after civil war. Princeton: Princeton University Press.

FRANCE 24. (2020, August 19). African Union suspends Mali's membership as international community condemns coup. Retrieved from https://www.france24.com/en/20200819-mali-coup-leaders-faceinternationalcondemnation-au-suspends-membership

Hultman, L., Kathman, J., \& Shannon, M. (2013). United Nations Peacekeeping and Civilian Protection in Civil War. American Journal of Political Science, 57(4), pp. 875-891. Retrieved from http://www.jstor.org/stable/23496662

Human Rights Watch. (2014). World Report 2014: Democratic Republic of Congo. Human Rights Watch. Retrieved from https://www.hrw.org/worldreport/2014/country-chapters/democraticrepublic-congo

International Labour Organization (ILO). (2020, April 08). The socio-economic impact of COVID-19 in fragile settings: Peace and social cohesion at risk. International Labour Organization (ILO). Retrieved from https://www.ilo.org/global/topics/employment-promotion/recoveryandreconstruction/WCMS_741158/lang--en/index.htm 
Khare, A. \& Lacroix J.P. (n.d). Peacekeepers help fragile countries navigate conflict and COVID-19. UN News. Retrieved from https://news.un.org/en/story/2020/04/1061092

Lee S., \& Bartels, S. (2020) 'They Put a Few Coins in Your Hand to Drop a Baby in You': A Study of Peacekeeper-fathered Children in Haiti, International Peacekeeping, 27(2), pp. 177-209, DOI: $10.1080 / 13533312.2019 .1698297$

Lessons-Learned Unit UN Department of Peacekeeping Operations. (1996). Multidisciplinary peacekeeping: Lessons from recent experience. Department of Peacekeeping Operations. Retrieved from https://reliefweb.int/sites/reliefweb.int/files/resources/C51B776A550FF 1E8C1256D57004B1BE0-dpko-multi-dec96.pdf

Losh J. (2020, April 10). Foreigners targeted in Central African Republic as coronavirus fears grow. The Guardian. Retrieved from https://www.theguardian.com/globaldevelopment/2020/apr/10/foreigners-central-african-republiccoronavirus-fears-grow

MALI Assemblée Nationale (National Assembly). (2016). General Information About the Parliamentary Chamber. Retrieved from http://archive.ipu.org/parline-e/reports/2201.htm

Martin, M. (2020, August 5). Supporting women during COVID-19 and beyond. United Nations Blogs. Retrieved from https://blogs.un.org/blog/2020/08/05/supporting-women-during-covid19-and-beyond/

MINUSMA. (2020, May 12). Trois Fois Plus de Femmes Élues aux Législatives 2020: Un Progrès Énorme Vers une Représentation Égale. Minusma. Retrieved from https://minusma.unmissions.org/trois-foisplus-de-femmes-élues-auxlégislatives-2020\%C2\%

MONUSCO. (2020, September 06). \#photodujour \#Mayi_Moya, \#North_Kivu,\#DRC: During their patrol for the protection of civilians \#MONUSCO peacekeepers from \#SouthAfrica distribute face masks and hand sanitizers to students in Mayi Moya village, North Kivu. \#coronavirus \#A4P.[Tweet]. https://twitter.com/MONUSCO/status/1302569765781876736 
Nagel R. \& Verveer. M. (2020, April 8). What the Pandemic Means for UN Peacekeeping Work. PassBlue Independent Coverage of the UN. Retrieved from https://www.passblue.com/author/robert-nagel

Norwegian Refugee Council. (2020, April 8). Armed conflict displaces 660,000 since UN call for global ceasefire. Norwegian Refugee Council. Retrieved from https://www.nrc.no/news/2020/may/armed-conflictdisplaces-660000since-un-call-for-global-ceasefire/

Office of the Special Adviser on Gender Issues and Advancement of Women (OSAGI). (n.d.). Landmark resolution on Women, Peace, and Security. United Nations. Retrieved from https://www.un.org/womenwatch/osagi/wps/

Ogharanduku V. (2017). Violent Extremism and Grievance in Sub-Saharan Africa, Peace Review, 29:2, 207-214. https://doi.org/10.1080/10402659.2017.1308732

PeaceWomen. (2019). Peacekeeping PeaceWomen. Retrieved from https://www.peacewomen.org/taxonomy/term/27

Perianes A. (2020, May 29). COVID-19: The Women, Peace, and Security Agenda at Risk. Retrieved from https://impakter.com/covid19-womenpeace-securityrisk/

Ruggeri, A., Dorussen, H., \& Gizelis, T. (2017). Winning the Peace Locally: UN Peacekeeping and Local Conflict. International Organization, 71(1). pp. 163-185. https://doi.org/10.1017/S0020818316000333

Sadeque, S. (2020, June 25). Children on the Frontline Covid-19 Increases Suffering of Children in Conflict. IPS.Retrieved from http://www.ipsnews.net/2020/06/covid-19-increases-suffering-ofchildren-inconflict/

Security Council Affairs Division. (2020, June 25). COVID-19 Exacerbating Tensions in Democratic Republic of Congo's Coalition Government,

United Nations Meetings Coverage and Press Releases. (2020, June 25)

Compounding Humanitarian Woes, Stabilization Mission Head Warns Security Council. Retrieved from https://www.un.org/press/en/2020/sc14228.doc.htm 
Sy Koumbou S. \& Betyna L. (2020, September 09). Nord-Kivu : La MONUSCO Va Se Redéployer dans la Zone de Mutwanga pour Répondre aux Souhaits de la Population. Retrieved from https://monusco.unmissions.org/nord-kivu-lamonusco-va-se-redéployerdans-la-zone-de-mutwanga-pour-répondre-auxsouhaits-de-la

UN DPKO (United Nations Department of Peacekeeping Operations). (2008). United Nations Peacekeeping Operations: Principles and Guidelines (The Capstone Doctrine). Retrieved from https://www.un.org/ruleoflaw/files/Capstone_Doctrine_ENG.pdf

United Nations Department of Global Communications (DGC). (n.d). United Nations peacekeeping continues vital work amid COVID-19 pandemic. United Nations. Retrieved from https://www.un.org/en/uncoronaviruscommunications-team/united-nations-peacekeepingcontinues-vital-workamid-covid-19

United Nations Interagency Framework Team for Preventive Action. (2012). Toolkit and Guidance for Preventing and Managing Land and Natural Resources Conflicts. Retrieved from https://www.un.org/en/events/environmentconflictday/pdf/GN_Renewa ble_Co nsultation.pdf

United Nations Peacekeeping. (n.d.). Mandates and the legal basis for peacekeeping. United Nations Peacekeeping Retrieved from https://peacekeeping.un.org/en/mandates-and-legal-basis-peacekeeping

United Nations Peacekeeping. (n.d.). Protection of civilians mandate. United Nations Peacekeeping. Retrieved from https://peacekeeping.un.org/en/protection-ofcivilians-mandate

United Nations Peacekeeping. (n.d.). Terminology. Retrieved from https://peacekeeping.un.org/en/terminology

UN News. (2020, April 28). As pandemic encroaches on Abyei, tensions rise over disputed territory straddling Sudan, South Sudan. UN News. Retrieved from https://news.un.org/en/story/2020/04/1062762

UN News. (2020, June 23). UN condemns killing of Indonesian peacekeeper in DR Congo. UN News. Retrieved from https://news.un.org/en/story/2020/06/1066912 
UN Peacekeeping. (2020, April 20). "Protect, Help, Explain”: UN Peacekeeping responds to COVID-19. UN Peacekeeping. Retrieved from https://www.un.org/africarenewal/news/coronavirus/“"protect-helpexplain"un-peacekeeping-responds-covid-19

UN Peacekeeping. (2020, May 28). Women peacekeepers on the front lines of COVID-19. Retrieved from https://medium.com/we-thepeoples/womenpeacekeepers-on-the-front-lines-of-covid-19$7235 \mathrm{a} 6 \mathrm{fd} 9615$

UN Women. (2020). Women, peace and security, and COVID-19 in Asia and The Pacific. Retrieved from https://asiapacific.unwomen.org//media/field\%20office\%20eseasia/docs/publications/2020/03/ap-wpscovid-inasia-pacific.pdf?la=en $\& v s=1416$

\section{(c) $($ () $\ominus$}

EY NO ND This work is licensed under a Creative Commons AttributionNonCommercial-NoDerivatives 4.0 International License.

(C) (AMANDA M. MAKOSSO, 2020)

Published by the Journal of Intelligence, Conflict and Warfare and Simon Fraser University

Available from: https://jicw.org/ 